\title{
How to Realize Multifunctional Land Use as a Contribution to Sustainable Development
}

\author{
Johan Bouma* \\ Soil Science, Wageningen University, Wageningen, Netherlands
}

Keywords: primary production, water quality, nutrient cycling, biodiversity, climate regulation

\section{MULTIFUNCTIONALITY IN RELATION TO THE UN SUSTAINABLE DEVELOPMENT GOALS}

Schröder et al. (2020) have identified five well documented reasons why farmers are reluctant to adopt multifunctional land use (MLU), pointing out correctly that just advocating MLU without considering farmers attitudes (Veerman et al., 2020) is meaningless. Their rather pessimistic analysis, which questions whether farmers can be convinced to embrace MLU, is very well documented and increases our knowledge and understanding as required by any scientific analysis. Still, the analysis can also be more positively focused on exploring ways to enhance application of MLU by farmers, taking into account their demands and concerns in a multidisciplinary context (e.g. Ingram et al.,

OPEN ACCESS

Edited by:

Pascal Boivin,

University of Applied Sciences Western Switzerland, Switzerland

Reviewed by:

Philippe C. Baveye, AgroParisTech Institut des Sciences et Industries du Vivant et de L'environnement, France

*Correspondence: Johan Bouma

johan.bouma@planet.nI

Specialty section:

This article was submitted to Soil Processes,

a section of the journal

Frontiers in Environmental Science

Received: 23 October 2020 Accepted: 07 January 2021 Published: 02 February 2021

Citation:

Bouma J (2021) How to Realize Multifunctional Land Use as a Contribution to

Sustainable Development. Front. Environ. Sci. 9:620285. doi: 10.3389/fenvs.2021.620285 2010; Kahan, 2015; O’Sullivan et al., 2018; Krzywoszynska, 2019; Schulte et al., 2019; Salazar et al., 2020). Why do so? Because MLU is crucial when considering the UN Sustainable Development Goals (SDGs) that point a way to a future where emphasis should not only be on crop production (SDG2) but simultaneously on a number of associated environmental conditions in terms of good quality of ground- and surface water (SDG6), low emission of greenhouse gasses and carbon capture (SDG13) and biodiversity and nature preservation (SDG15). The EU-Green Deal, presented in 2019, follows the SDG principles. Both the SDGs and the Green Deal, not mentioned by Schröder et al. (2020), are important because they put sustainable development in a clear, transparent and legally binding framework while creating specific goals to aim at, defining ecosystem services related to land use (Robinson et al., 2012; Keesstra et al., 2016).

This opinion paper will argue that setting specific environmental goals, initiating payment procedures for ecosystem services and introducing goal oriented policies, can potentially overcome the reluctance of farmers that now: "feel in the dark what to do" (Schröder et al., 2020). But if the scientific community does not indicate sources of light who will? Moreover, computer analysis of the soil-water-atmosphere-plant system can quantify effects of soil degradation but, more importantly, the major future effects of climate change that should already affect the current discours by: "quantifying long term implications" that are now largely absent according to Schröder et al. (2020).

\section{CHALLENGES FACED BY MODERN FARMERS}

Farmers are hestitant about multifunctionality because of at least five problems: 1) insufficient visible proof of soil degradation and benefits of preventive vs. curative measures; 2) limited awareness of long term synergies; 3) insufficient renumeration of ecosystem services: 4) lacking trustworthy knowledge; 5) absence of incentives and regulations on soil management and their enforcement (Schröder et al., 2020). Reference will be made to these five problems in the remaining part of this paper. 
Farmers are besieged by advocates of particular farming systems: biological, biological-dynamic, circular, natureinclusive, regenerative, precision, and others. Farmers don't see: "a point at the horizon" to aim for, nor do complex agricultural policies show the way. The UN-SDGs and the EUGreen Deal can, however, provide this future perspective but this needs a substantial research effort focused on the measurement of ecosystem services, contributing to the various SDGs. What does this imply?

\section{CAN MEASUREMENT OF ECOSYSTEM SERVICES PROVIDE AN ENLIGHTENING AND PROFITABLE FUTURE ROADMAP?}

1) Food production responds to market forces and determines food quality, that can be affected by soil pollutants. Food quality is now closely monitored by governmental services (SDGs 2,3). Farmers are part of the food chain and increased emphasis on sustainability by market forces has a positive effect on consumption patterns, in turn stimulating farmers to become more aware of the need for multifunctionality. 2) Water quality (SDG6) is regulated by the EU Water Framework, requiring farmers to adjust their fertilization practices to prescribed application rates. But water qualities are not measured onfarm but elsewhere or not at all and this fuzziness creates lack of engagement (e.g. Bouma, 2011). Why not instead measure water quality at farm level? 3) In future, regulations are likely to be introduced on carbon capture as part of climate mitigation policies (SDG13). Why not take a pro-active approach and explore which soils have potential for carbon capture and which management procedures can restrict release of greenhouse gasses? (Amelung et al., 2020). Still, there is scepticism about the feasibility of carbon sequestration in soil and more field research is needed to show its real potential (Amundson and Biardeau (2018), and 4) A similar discours applies to life on land (SDG15) covering first the quality of the soil biome, essential for soil functioning where \% organic matter can initially act as a suitable proxy value, and, second, the effects of soil management on surrounding nature as partly expressed by the SDGs 6 and 13 .

The time has passed that monitoring necessarily implied long, tedious and costly procedures involving field sampling and laboratory analysis. Now, automatic field equipment is available to measure water quality; satellites and drones can measure greenhouse gasses and crop conditions, proximal sensors can rapidly measure soil organic matter content (e.g. Viscarra Rossel et al., 2010). All these measurements have to be made at prescribed moments in time and threshold values have to be defined separating favorable from unfavorable conditions for each of the ecosystem services at any location. For example, groundwater quality is already defined considering a threshold value of $50 \mathrm{mg}$ nitrates/litre. Also, dynamic simulation models are available for the soil-water-atmosphere-plant system both at national and European scale that allow to estimate losses of nitrogen, phosphorous and greenhouse gases to air and water (e.g. De Vries et al., 2015) and that show the hotspots where the needed improvements in nutrient use efficiency are most urgent to protect air and water quality (e.g. De Vries and SchulteUebbing, 2020). They are already widely applied to characterize regional environmental conditions of water, air and vegetation. They could also be applied at farm level when detailed data are available.

\section{HOW TO IMPROVE COMMUNICATION BETWEEN FARMERS AND THE SCIENCE COMMUNITY?}

How to communicate effectively with farmers as these new technological opportunities arise? A key problem is the fact that many innovative management procedures are available but not applied. Every farmer is different and tailor-made personal advice by commercially independent experts may work better than an impersonal computer-guided Decision Support System. Bampa et al. (2019) indeed report that: "farmers recommended small participatory research projects building momentum with colleagues to try new approaches". Joint work of scientists and farmers on farms acting as: "Living Labs" with emphasis on joint learning rather than on topdown advice (Veerman et al., 2020) would be important to facilitate knowledge transfer and to generate new knowledge, addressing problem 4 . And, finally, technological developments can support the upbeat opinion that: "what is good for business can be good for the environment". An example is precision farming, applying agrochemicals at the right time, the right place and in the right way cutting environmental pollution and the cost of fertilizer and biocide use by $25 \%$ in a case study (e.g. Stoorvogel et al., 2015). Higher net returns for farmers can also be achieved by lowering costs! Why not promote this and try to generate other examples where striving for environmental quality is not necessarily bad for business?

Having provided good monitoring data and when measured values are below the various thresholds, tailor-made payment for provided ecosystem services could follow and environmental laws and regulations could focus on goals rather than on means to reach goals, addressing problem 5 (Vrebos et al., 2017). The proposed European Common Agricultural Policy 2021-2027 has a budget of 350 billion $€$. Recent discussions suggest that part of the funds will still be assigned to pillar 1 (direct payment on a per/ ha basis) but an increasing quantity to pillar 2, providing ecosystem services. Research, focused on the assessment of ecosystem services, as discussed above, could provide a sound basis for such payments, addressing problem 3. Still, the issue of payment for ecosystem services still needs research on methodology, thresholds and amounts to be paid where, again, the example of the ecosystem service: "water quality" can act as an example, except for the amount to be paid, an issue that has not yet been addressed. The literature so far is partly skeptical about the feasibility of payment for ecosoystem services (e.g. Chalhoub et al., 2020; Baveye et al., 2013; Baveye et al., 2016) while also positive results have been reported (Jónsson and Daviðsdóttir, 2016). 
Translating the nebulous concept of sustainable development into specified ecosystem services (with associated payments) would engage farmers, the more so because they can then focus on the type of management corresponding with their particular farming style, addressing problem 4 . Every farmer is different and faces different opportunities and conditions. The possibility that: "anything goes", as long as the environmental thresholds are not exceeded, would present a big relief to the farming community!

\section{CLIMATE CHANGE AS A CHALLENGE}

However, the: "point at the horizon" right now is quite different from the one in 2050 and beyond when many areas in the world will become too dry and hot for agriculture, when areas with fertile soils near rivers and the sea may flood due to sea-level rise and when elsewhere dry periods will expand while showers become more intense (IPCC, 2019). But areas with still suitable climates for agriculture and healthy soils in future have great potential and this would be a welcome and engaging message for worried farmers in such areas. An Italian case study showed that healthy soils made significant contributions to SDG2, also when exploring the effects of climate change up to the year 2,100 based on IPCC scenarios (Bonfante

\section{REFERENCES}

Amelung, W., Bossio, D., de Vries, W., Kögel-Knabner, I., Lehman, J., Amundson, R., et al. (2020). Towards a global-scale soil climate mitigation strategy. Nat. Commun. doi:10.1038/s41467-020-18887-7

Amundson, R., and Biardeau, L. (2018). Opinion: soil carbon sequestration is an elusive climate mitigation tool. Proc. Natl. Acad. Sci. USA 115, 11652-11656. doi:10.1073/pnas.1815901115

Bampa, F., O’Sullivan, L., Madena, K., D Sandén, T., Spiegel, H., Hendriksen, C. B., et al. (2019). Harvesting European knowledge on soil functions and land management using multi-criteria decision analysis. Soil Use Manag. 35, 6-20. doi:10.1111/sum.12506

Baveye, P. C., Baveye, J., and Gowdy, J. (2013). Monetary valuation of ecosystem services: it matters to get the timeline right. Ecol. Econ. 95, 231-235. doi:10. 1016/j.ecolecon.2013.09.009

Baveye, P. C., Baveye, J., and Gowdy, J. (2016). Soil "ecosystem" services and natural capital: critical appraisal of research on uncertain ground. Front. Environ. Sci. 4, 41. doi:10.3389/fenvs.2016.00041

Bonfante, A., Basile, A., and Bouma, J. (2020). Targeting the soil quality and soil health concepts when aiming for the United Nations sustainable development goals and the EU green deal. Soils 6, 1-14. doi:10.5194/soil-6-1-2020

Bouma, J. (2011). Applying indicators, threshold values and proxies in environmental legislation: a case study for Dutch dairy farming. Environ. Sci. Pol. 14, 231-238. doi:10.1016/j.envsci.2010.12.001

Chalhoub, M., Gabrielle, B., Tournebize, J., Chaumont, C., Maugis, P., Girardin, C., et al. (2020). Direct measurement of selected soil services in a drained agricultural field: methodology development and case study in Saclay (France). Ecosyst. Serv. 42, 101088. doi:10.1016/j.ecoser.2020.101088

De Vries, W., Kros, J., Dolman, M. A., Vellinga, Th. V., de Boer, H. C., Sonneveld, M. P. W., et al. (2015). Environmental impacts of innovative dairy farming systems aiming at improved internal nutrient cycling: a multi-scale assessment. Sci. Total Environ. 536, 432-442. doi:10.1007/978-3-319-71065-5_11-1

De Vries, W., and Schulte-Uebbing, L. (2020). "Required changes in nitrogen inputs and nitrogen use efficiences to reconcile agricultural productivity with et al., 2020). This study, based on modeling the soil-wateratmosphere-plant system, also indicated production losses resulting from soil degradation processes such as erosion and compaction as well as potential gains by raising the organic matter content, both under current and future climate conditions. This way, "long-term implications" can be quantified (addressing problems 1 and 2).

How to feed 9.7 billion world inhabitants in 2050 is a key question and that farmers put climate regulation at the bottom of their listing of important multifunctional factors in Schröder et al. (2020), painfully demonstrates that the scientific community faces a challenge to improve their communication practices.

\section{AUTHOR CONTRIBUTIONS}

General commentary and opinion by JB.

\section{ACKNOWLEDGMENTS}

Suggestions by the reviewer and editor and discussions within the EC. Mission Board for Soil Health and Food are gratefully acknowledged.

water and air quality objectives in the EU-27” in Proceedings 842. Int. Fertilizer Society. www.fertilizer-society.org.

Ingram, J., Fry, P., and Mathieu, A. (2010). Revealing different understandings of soil held by scientists and farmers in the context of soil protection and management. Land Use Pol. 27, 51-60. doi:10.1016/j.landusepol.2008. 07.005

IPCC (2019). “Climate Change and Land. An IPCC Special Report on climate change, desertification, land degradation, sustainable land management, food security and greenhouse gas fluxes", in Chapter 5: Food Security (C. Mbow and C. Rosenschweig, coordinating lead authors). www.ipcc.ch, p. 437-550.

J. F. Salazar, C. Granjou, M. Kearnes, A. Krzywoszynska, and M. Tironi (2020). "Thinking with soils" in Material politics and social theory (London, New York: Bloomsbury Academic).

Jónsson, J. O. G., and Davíðsdóttir, B. (2016). Classification and valuation of soil ecosystem services. Agric. Syst. 145, 24-38. doi:10.1016/j.agsy.2016.02.0100308$521 \mathrm{X}$

Kahan, D. M. (2015). What is the science of "Science Communication?. J. Sci. Commun. 14 (3), 1-10. doi:10.2139/ssrn.2562025

Keesstra, S. D., Bouma, J., Wallinga, J., Tittonell, P., Smith, P., Cerda, A., et al. (2016). The significance of soils and soil science towards realization of the United Nations Sustainable development goals. Soil 2, 111-128. doi:10.5194/ soil-2-111-2016

Krzywoszynska, A. (2019). Making knowledge and meaning in communities of practice: what role may science play? The case of sustainable soil management in England. Soil Use Manag. 35 (1), 160-168. doi:10.1111/ sum. 12487

O'Sullivan, L., Wall, D., Creamer, R., Bampa, F., and Schulte, R. P. O. (2018). Functional land management: bridging the think-do- gap using a multistakeholder science policy interface. Ambio 47, 210-230. doi:10.1007/ s13280-017-0983-x

R. A. Viscarra-Rossel, A. McBratney, and B. Minashy (2010). "Proximal soil sensing" in Progress in soil science (Heidelberg, London, New York: Springer Publ. Co. Dordecht). doi:10/1007/978-90-481-8859-8

Robinson, D. A., Hockley, N., Domiunati, E., Lebron, I., Scow, K. M., Reynolds, B., et al. (2012). Natural capital, ecosystem services and soil change: why soil 
science must embrace an ecosystems approach. Vadose Zone J. 11 (1), 11-25. doi:10.2136/vzj2011.0051

Schröder, J. J., ten Berge, H. F. M., Bampa, F., Creamer, R. E., Giraldez-Cervera, J. V., Hendriksen, C. B., et al. (2020). Multifunctional land use is not self evident for European farmers: a critical review. Front. Environ. Sci. doi:10.3389/fenvs. 2020.575466

Schulte, R. P. O., O'Sullivan, L., Vrebos, D., Bampa, F., Jones, A., and Staes, J. (2019). Demands on land: mapping competing societal expectations for the functionality of agricultural soils in Europe. Env. Sci. Policy. 100, 113-125.

Stoorvogel, J. J., Kooistra, L., and Bouma, J. (2015). "Managing soil variability at different spatial scales as a basis for precision agriculture. Chapter 2," in Soil specific farming: precision agriculture. Advances in soil science. Editors R. Lal and B.A. Stewart (Boca Raton, FL, USA: CRC Press, Taylor Francis Group), 37-73.

Veerman, C., Bastioli, C., Biro, B., Bouma, J., Cienciala, E., Emmett, B., et al. (2020). Caring for soil is caring for life-Ensure $75 \%$ of soils are healthy by 2030 for food, people, nature and climate, Independent expert report. Luxembourg: Eur. Comm. Publ. Office of the Eur. Union.

Vrebos, D., Bampa, F., Creamer, R. E., Gardi, C., Ghaley, B. B., Jones, A., et al. (2017). The impact of policy instruments on soil multifunctionality in the European Union. Sustainability 9 (3), 407. doi:10.3390/su9030407

Conflict of Interest: The author declares that the research was conducted in the absence of any commercial or financial relationships that could be construed as a potential conflict of interest.

Copyright (c) 2021 Bouma. This is an open-access article distributed under the terms of the Creative Commons Attribution License (CC BY). The use, distribution or reproduction in other forums is permitted, provided the original author(s) and the copyright owner(s) are credited and that the original publication in this journal is cited, in accordance with accepted academic practice. No use, distribution or reproduction is permitted which does not comply with these terms. 